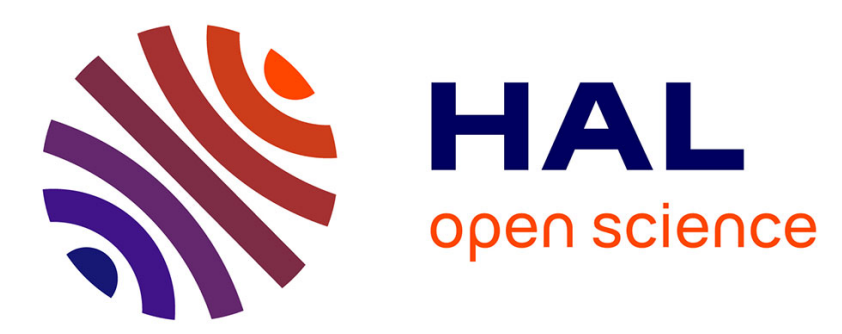

\title{
Inhibitory Effects of Secondary Metabolites from the Lichen Stereocaulon evolutum on Protein Tyrosine Phosphatase 1B
}

Thi Huyen Vu, Olivier Delalande, Claudia Lalli, Stefanie Reider, Solenn Ferron, Joel Boustie, Birgit Waltenberger, Françoise Lohézic-Le Dévéhat

\section{To cite this version:}

Thi Huyen Vu, Olivier Delalande, Claudia Lalli, Stefanie Reider, Solenn Ferron, et al.. Inhibitory Effects of Secondary Metabolites from the Lichen Stereocaulon evolutum on Protein Tyrosine Phosphatase 1B. Planta Medica, 2021, 87 (09), pp.701-708. 10.1055/a-1334-4480 . hal-03157370

\author{
HAL Id: hal-03157370 \\ https://hal.science/hal-03157370
}

Submitted on 27 Oct 2021

HAL is a multi-disciplinary open access archive for the deposit and dissemination of scientific research documents, whether they are published or not. The documents may come from teaching and research institutions in France or abroad, or from public or private research centers.
L'archive ouverte pluridisciplinaire HAL, est destinée au dépôt et à la diffusion de documents scientifiques de niveau recherche, publiés ou non, émanant des établissements d'enseignement et de recherche français ou étrangers, des laboratoires publics ou privés. 


\section{Complimentary and personal copy for}

Thi Huyen Vu, Olivier Delalande, Claudia Lalli, Stefanie Reider, Solenn Ferron, Joel Boustie, Birgit Waltenberger, Françoise Lohézic-Le Dévéhat

Inhibitory Effects of Secondary Metabolites from the Lichen Stereocaulon evolutum on Protein Tyrosine Phosphatase 1B

DOI 10.1055/a-1334-4480

Planta Med

This electronic reprint is provided for noncommercial and personal use only: this reprint may be forwarded to individual colleagues or may be used on the author's homepage. This reprint is not provided for distribution in repositories, including social and scientific networks and platforms.

Publishing House and Copyright: 


\section{Inhibitory Effects of Secondary Metabolites from the Lichen Stereocaulon evolutum on Protein Tyrosine Phosphatase 1B}

Authors

Thi Huyen Vu ${ }^{1}$, Olivier Delalande ${ }^{2}$, Claudia Lalli $^{1}$, Stefanie Reider ${ }^{3}$, Solenn Ferron ${ }^{1}$, Joel Boustie ${ }^{1}$, Birgit Waltenberger ${ }^{3 *} \mathbb{D}^{\mathbb{D}}$, Françoise Lohézic-Le Dévéhat ${ }^{1 *}$

Affiliations

1 University of Rennes, CNRS, ISCR - UMR 6226, Rennes, France

2 University of Rennes, CNRS, IGDR - UMR 6290, Rennes, France

3 Institute of Pharmacy/Pharmacognosy, University of Innsbruck and Center for Molecular Biosciences Innsbruck (CMBI), Innsbruck, Austria

Key words

lichen, depsidones, diphenylethers, protein tyrosine phosphatase 1B, Stereocaulaceae, Stereocaulon evolutum

\section{received} accepted after revision published online

\section{Bibliography}

Planta Med 2021

DOI $\quad 10.1055 / a-1334-4480$

ISSN 0032-0943

(c) 2021. Thieme. All rights reserved. Georg Thieme Verlag KG, Rüdigerstraße 14, 70469 Stuttgart, Germany

Correspondence

Dr. Birgit Waltenberger

Institute of Pharmacy/Pharmacognosy, University of Innsbruck and Center for Molecular Biosciences Innsbruck (CMBI) Innrain 80-82, 6020 Innsbruck, Austria

Phone: + 4351250758420 , Fax: + 4351250758499

birgit.waltenberger@uibk.ac.at

\section{Correspondence}

Dr. Françoise Lohézic-Le Dévéhat

UMR CNRS 6226 ISCR, Equipe CORINT, University of Rennes 1

2 avenue du Pr Leon Bernard, 35043 Rennes cedex, France

Phone: + 33223234816 , Fax: + 33223234711

francoise.le-devehat@univ-rennes1.fr
Supplementary material is available under
https://doi.org/10.1055/a-1334-4480

\section{ABSTRACT}

Protein tyrosine phosphatase $1 \mathrm{~B}$ plays a significant role in type 2 diabetes mellitus and other diseases and is therefore considered a new drug target. Within this study, an acetone extract from the lichen Stereocaulon evolutum was identified to possess strong protein tyrosine phosphatase $1 \mathrm{~B}$ inhibition in a cell-free assay $\left(\mathrm{IC}_{50}\right.$ of $\left.11.8 \mu \mathrm{g} / \mathrm{mL}\right)$. Fractionation of this bioactive extract led to the isolation of seven known molecules belonging to the depsidones and the related diphenylethers and one new natural product, i.e., 3-butyl-3,7-dihydroxy-5methoxy-1(3H)-isobenzofurane. The isolated compounds were evaluated for their inhibition of protein tyrosine phosphatase 1B. Two depsidones, lobaric acid and norlobaric acid, and the diphenylether anhydrosakisacaulon A potently inhibited protein tyrosine phosphatase $1 \mathrm{~B}$ with $\mathrm{IC}_{50}$ values of 12.9 , 15.1 , and $16.1 \mu \mathrm{M}$, respectively, which is in the range of the protein tyrosine phosphatase $1 \mathrm{~B}$ inhibitory activity of the positive control ursolic acid ( $\mathrm{IC}_{50}$ of $\left.14.4 \mu \mathrm{M}\right)$. Molecular simulations performed on the eight compounds showed that i) a contact between the molecule and the four main regions of the protein is required for inhibitory activity, ii) the relative rigidity of the depsidones lobaric acid and norlobaric acid and the reactivity related to hydrogen bond donors or acceptors, which interact with protein tyrosine phosphatase 1B key amino acids, are involved in the bioactivity on protein tyrosine phosphatase $1 \mathrm{~B}$, iii) the cycle opening observed for diphenylethers decreased the inhibition, except for anhydrosakisacaulon A where its double bond on C-8 offsets this loss of activity, iv) the function present at C-8 is a determinant for the inhibitory effect on protein tyrosine phosphatase $1 \mathrm{~B}$, and $v$ ) the more hydrogen bonds with Arg221 there are, the more anchorage is favored.

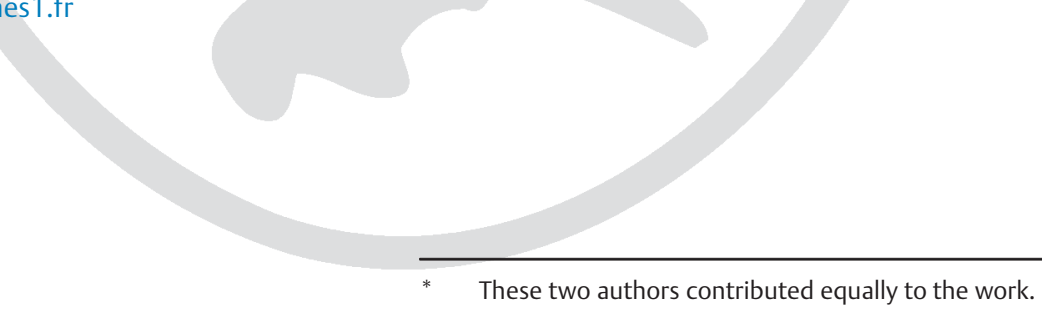




\section{Introduction}

Control of cellular protein tyrosine phosphorylation is essential for cell growth, cell differentiation, and other cellular processes. Its dysregulation is associated with several human diseases. The phosphorylation and dephosphorylation of protein tyrosine is controlled by protein tyrosine kinases (PTKs) and phosphatases (PTPs), which are important factors of cellular signaling pathways [1]. The PTP that was isolated first was protein tyrosine phosphatase 1B (PTP1B). The crystal structure of human PTP1B, including the structure of its catalytic domain, was published in 1994 [2]. Since then, numerous studies showed the significant role of PTP1B in various cellular mechanisms implied in pathologies such as type 2 diabetes mellitus and obesity [3], breast cancer [4,5], atherosclerosis and cardiovascular disease [6], nonalcoholic fatty liver disease [7], and cerebral ischemia [8]. Thus, this enzyme is now considered a new drug target. Several studies reported the identification of PTP1B inhibitors that could regulate disturbed cell pathways $[9,10]$. These inhibitors target the catalytic domain of PTP1B (amino acids 30-278), which comprises a catalytic loop of eight amino acid residues (His214-Arg221). This loop binds to the arylphosphate residue of the substrate and contains the active site nucleophile Cys215. It also binds to two other sites, i.e., Arg24 and Arg254 as well as Tyr46 and Asp48. Upon ligand binding, a comprehensive change in the conformation occurs, which activates the enzyme. The space between amino acids 179-186, known as the WPD loop, enlarges and encloses part of the substrate, which enables hydrophobic interactions of the substrate with the protein [3]. Natural products are also an important source of new scaffolds of PTP1B inhibitors. Several compound classes have been shown to inhibit PTP1B, such as phenolic acids, flavonoids, chalcones, dammarane-type triterpenoids, isoflavonoids, alkaloids, and coumarins [3, 9, 11].

Lichens as symbiotic organisms composed of fungi, algae, or cyanobacteria produce a wide range of secondary metabolites. Various biological activities have already been ascribed for lichen compounds, e.g., antibacterial, antifungal, antiviral, antitumor, anti-HIV, antioxidant, and anti-inflammatory effects [12]. Moreover, some of these compounds were described as playing a role in the control of glucose via insulin [13-16]. Therefore, natural products from lichens might be a highly valuable source for the identification of new PTP1B inhibitors.

Hoping to find novel inhibitors of this enzyme, the acetone extract of the lichen Stereocaulon evolutum Graewe, a member of the Stereocaulaceae family, was identified to possess strong PTP1B inhibitory activity and was thus selected for further analyses. Fractionation of this bioactive extract led to the isolation of seven known compounds belonging to the classes of depsidones and diphenylethers and a new isobenzofuranone. They were also subjected to a cell-free PTP1B inhibition assay, and docking simulation of the isolated compounds was realized for elucidating the amino acids involved in PTP1B inhibition.

\section{Results and Discussion}

Powdered S. evolutum material was extracted successively with $n$ hexane and acetone. The obtained extracts were investigated on their ability to inhibit PTP1B in a cell-free assay. Both extracts significantly inhibited the PTP1B enzyme in a concentration-dependent manner. However, while the $n$-hexane extract showed only weak inhibition of PTP1B with an $\mathrm{IC}_{50}$ of $32.8 \mu \mathrm{g} / \mathrm{mL}\left[\mathrm{Cl}_{95}( \pm)\right.$ 9.62/13.6], the acetone extract showed potent PTP1B inhibition with an $\mathrm{IC}_{50}$ of $11.8 \mu \mathrm{g} / \mathrm{mL}\left[\mathrm{Cl}_{95}( \pm)\right.$ 2.42/3.03] (Fig. 1S, Supporting Information). Therefore, the acetone extract was selected for further investigation.

The S. evolutum acetone extract was fractionated by means of chromatographic techniques, including silica gel column chromatography (CC), Sephadex CC, and semipreparative HPLC, leading to the isolation of eight compounds ( $\bullet$ Fig. 1 ). Compounds 1-7 were identified as two depsidones, i.e., lobaric acid (1) [17] and norlobaric acid (2), and five diphenylethers, i.e., lobarin (3), sakisacaulon A (4), 8-methyl sakisacaulon A (5), anhydrosakisacaulon A (6), and sakisacaulon A esterified in C-7 (7) [15], by interpretation of NMR and MS spectral data (Figs. 2S-15S and Tables 15 and 2S, Supporting Information).

Compound 8 was obtained as a brown viscous liquid. Its molecular formula was assigned as $\mathrm{C}_{13} \mathrm{H}_{16} \mathrm{O}_{5}$ from the HR-ESI-MS ion at $\mathrm{m} / \mathrm{z} 275.0895\left([\mathrm{M}+\mathrm{Na}]^{+}\right)$. The UV spectrum with absorption maxima $\lambda_{\max }(\log \varepsilon)$ at 229 (4.34), 259 (4.21), and 295 (3.91) nm suggested that 8 comprises a $\gamma$-lactone ring. Its IR spectrum showed absorption bands corresponding to a hydroxyl group ( $v_{\max }$ $\left.3374 \mathrm{~cm}^{-1}\right)$, an aliphatic chain $\left(v_{\max } 2957 \mathrm{~cm}^{-1}\right)$, and aromatic rings $\left(v_{\max } 1694\right.$ and $\left.1614 \mathrm{~cm}^{-1}\right)$. The ${ }^{1} \mathrm{H}$ NMR spectrum exhibited signals of two aromatic protons $\left(\delta_{H} 6.44\right.$ and 6.46), one methoxy $\left(\delta_{\mathrm{H}} 3.86\right)$, and one methyl group $\left(\delta_{\mathrm{H}} 0.89\right)$. Multiplet signals at $\delta_{\mathrm{H}}$ 1.28-1.46 corresponding to methylene groups including four protons and a triplet signal at $\delta_{\mathrm{H}} 2.28$ corresponding to a methylene group with two protons suggested the presence of an aliphatic chain. The COSY experiment confirmed the presence of an $n$-butyl side chain and the connectivity between $\mathrm{H}-3$ and $\mathrm{H}-5$. The ${ }^{13} \mathrm{C}$ NMR spectrum of 8 comprised 12 carbon signals, including four aliphatic carbons, indicating the proposed aliphatic chain. The HMBC spectrum showed the following connectivities: aromatic H-3 $\left(\delta_{H} 6.46\right)$ with C-7 $\left(\delta_{C} 170.2\right), C-4\left(\delta_{C} 166.7\right), C-1\left(\delta_{C}\right.$ $104.4)$, and $C-5\left(\delta_{C} 102.1\right)$, aromatic $H-5\left(\delta_{H} 6.44\right)$ with $C-4\left(\delta_{C}\right.$ $166.7), \mathrm{C}-1\left(\delta_{\mathrm{C}} 104.4\right)$, and $\mathrm{C}-3\left(\delta_{\mathrm{C}} 101.9\right)$, aliphatic $\mathrm{H}-10$ with $\mathrm{C}-$ $9\left(\delta_{C} 39.9\right)$ and $C-11\left(\delta_{C} 22.3\right)$, aliphatic $\mathrm{H}-11$ with $\mathrm{C}-9\left(\delta_{C} 39.9\right)$, $\mathrm{C}-10\left(\delta_{\mathrm{C}} 25.5\right)$, and $\mathrm{C}-12\left(\delta_{\mathrm{C}} 13.6\right)$, and aliphatic $\mathrm{H}-12$ with $\mathrm{C}-10$ $\left(\delta_{C} 25.5\right)$ and $C-11\left(\delta_{C} 22.3\right)$. These analyses allowed for proposing the chemical structure of 8 as 3-butyl-3,7-dihydroxy-5-methoxy-1 $(3 \mathrm{H})$-isobenzofurane. However, despite experiments performed using different deuterated solvents and different temperatures (data not shown), the signal of C-8 was not visible in the ${ }^{13} \mathrm{C} N M R$ spectrum due to a keto-enol tautomerism, as previously observed for alectoronic acid [18]. To verify the hypothesis of the presence of a hydroxyl group in position 8, compound 8 was acetylated (Text 1S, Supporting Information). Its chemical structure was confirmed by comparison of the NMR data of 8 with the data obtained by 1D and 2D NMR analysis of the acetylated derivatives 8a-8c (Fig. 16S-20S and Table 3S, Supporting Information).

To confirm that 8 is a natural product present in S. evolutum and not an artefact generated during the isolation process, further extraction experiments were conducted. Lichen material was extracted with dichloromethane, ethyl acetate, tetrahydro- 


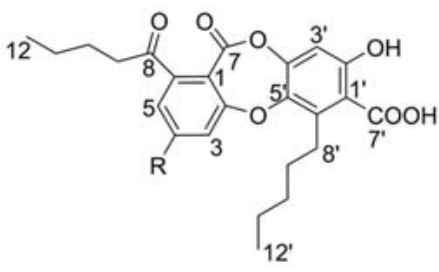

$1 \mathrm{R}=\mathrm{OCH}_{3}$ $2 \mathrm{R}=\mathrm{OH}$

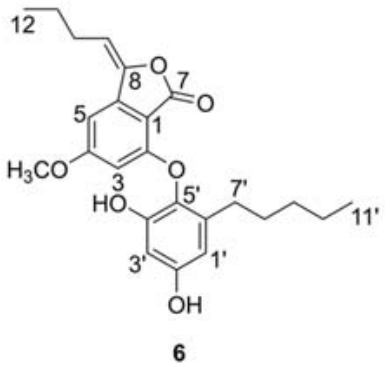

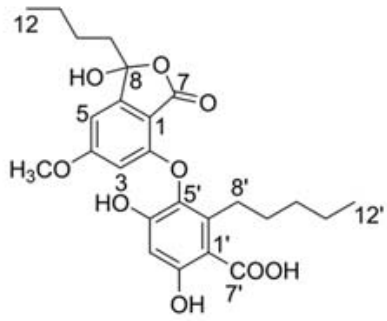

3

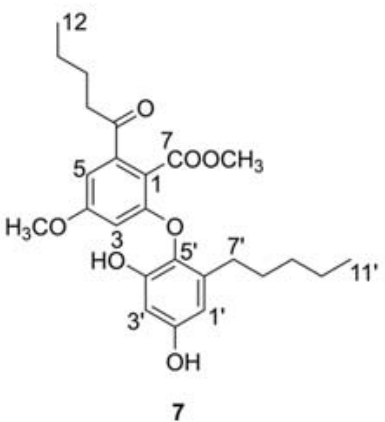

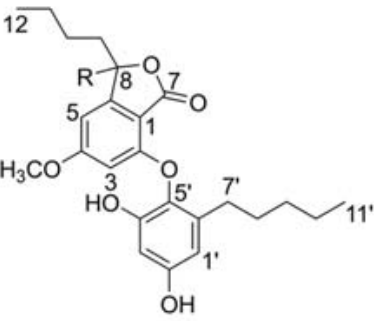

$4 \mathrm{R}=\mathrm{OH}$ $5 \mathrm{R}=\mathrm{OCH}_{3}$

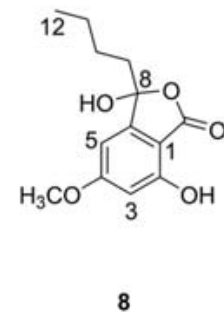

- Fig. 1 Chemical structures of lobaric acid (1), norlobaric acid (2), lobarin (3), sakisacaulon A (4), 8-methyl sakisacaulon A (5), anhydrosakisacaulon A (6), sakisacaulon A esterified in C-7 (7), and 3-butyl-3,7-dihydroxy-5-methoxy-1(3H)-isobenzofurane (8) isolated from S. evolutum.

furan, and $\mathrm{MeOH}$, respectively. The generated extracts, including the initially prepared extracts, were subjected to LC-MS analysis. Retention times and UV and MS spectra were assessed to compare the metabolic profiles of the extracts. Compound 8 was identified in all extracts independent of the extraction solvent (Fig. 21S, Supporting Information). Therefore, $\mathbf{8}$ is suspected to be a natural compound, which might be involved in the biosynthesis of the diphenylethers. A biogenetic relationship is proposed between 1 and the diphenylethers but also between 1, 4, and 8 (Fig. 22S, Supporting Information).

While 8 is a new natural product, $\mathbf{1}$ is commonly found in the Stereocaulon genus. Compound 2 was first identified in S. evolutum [15] and later also in Stereocaulon paschale [16]. Compound 3 was previously found in the lichen Stereocaulon halei [19] and 4 was already found in Stereocaulon sasakii [20]. Compounds 5, 6, and 7 were reported as degradation products of lobaric acid from Stereocaulon azoreum [21]. Compound 5 was also isolated from Stereocaulon alpinum [13].

Compounds 1-8 were tested for their PTP1B inhibitory effects. Except for 8, which was inactive, all compounds inhibited PTP1B in a concentration-dependent manner ( $\vee$ Fig. 2 and Fig. 23S, Supporting Information) with $\mathrm{IC}_{50}$ values between 12.9 and $67.4 \mu \mathrm{M}$ ( $\triangleright$ Table 1). The depsidones 1 and 2 , differing only in a methyl group in position 4, and the diphenylether 6 displayed the highest inhibitory effects on PTP1B $\left(\mathrm{IC}_{50}=12.9,15.1\right.$, and $16.1 \mu \mathrm{M}$, respectively), which were in the same range as the activity of the positive control ursolic acid $\left(\mathrm{IC}_{50}=14.4 \mu \mathrm{M}\right)$. Compounds 4 and 5 , which differ from 6 only by the presence of a hydroxyl and a methoxy function, respectively, instead of the double bond be- tween C8 and C9, showed only moderate PTP1B inhibitory activity with $I_{50}$ values of 37.5 and $67.4 \mu \mathrm{M}$, respectively. Therefore, it seems that the double bond is more beneficial for the inhibiting potential. Moreover, the observed results suggest that the carboxylic function of 3 is not important for PTP1B inhibition because 3 and 4 , which differ only in a carboxylic group in position 1', exhibited similar $I_{50}$ values (35.4 and $37.5 \mu \mathrm{M}$, respectively). Finally, the inactivity of 8 (residual PTP1B activity of $94.5 \%$ at $100 \mu \mathrm{M}$ ) suggests that the absence of one moiety of the diphenylether results in the loss of the inhibitory activity. Seo et al. [13] previously reported the isolation of 1 and two diphenylethers from S. alpinum, among them 5, and their PTP1B inhibitory activity, showing an about 8-fold higher activity of 1 compared to 5, which is in accordance with the results of the present study. They suggested that the carboxylic function at C -1 ' plays an important role in PTP1B inhibition. However, our results, in particular the comparison of the activities of 3 and 4 , do not confirm this hypothesis. Nevertheless, the activities we observed for 4,5 , and 7 suggest that the presence of a methoxy group in position 8 instead of a hydroxyl group and a methyl esterification might decrease the inhibitory activity, which confirms the hypothesis that acidic protons are important for PTP1B inhibition. However, this was not the case for the depsidones 1 and 2, where methylation of the hydroxyl group in position 4 did not reduce the bioactivity.

To confirm these hypotheses and to explain the obtained results, we performed molecular docking studies of 1-8 onto human PTP1B. The contact frequency mapping along the PTP1B primary sequence indicates that four main regions of the protein are in contact with 1-7 ( $\bullet$ Fig. 3). Those regions correspond to a loop 

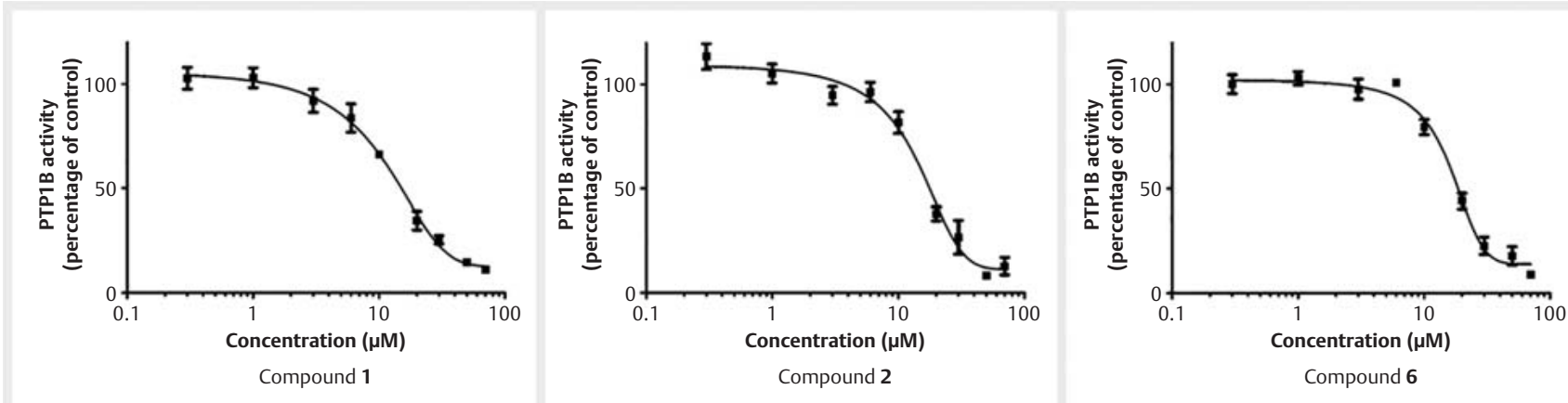

- Fig. 2 Concentration-dependent inhibition of PTP1B by compounds 1, 2, and 6, given as residual activity in $\%$ of the uninhibited control (100\%, vehicle $=$ DMSO). Nine concentrations $(0.3,1,3,6,10,20,30,50,70 \mu \mathrm{M})$, respectively, were evaluated to establish the sigmoidal dose-response curves by nonlinear regression $(n=3)$.

- Table 1 Inhibitory effects of compounds 1-8 isolated from S. evolutum on PTP1B.

\begin{tabular}{|c|c|c|}
\hline Compound & $\mathrm{IC}_{50}(\mu \mathrm{M})^{\mathrm{a}}$ & $\mathrm{Cl}_{95}( \pm)^{\mathrm{b}}$ \\
\hline Lobaric acid (1) & 12.9 & $2.6 / 3.2$ \\
\hline Norlobaric acid (2) & 15.1 & $2.9 / 3.5$ \\
\hline Lobarin (3) & 35.4 & $26.3 / 102.3$ \\
\hline Sakisacaulon A (4) & 37.5 & $22.9 / 58.8$ \\
\hline 8-Methyl sakisacaulon A (5) & 67.4 & $11.1 / 13.3$ \\
\hline Anhydrosakisacaulon (6) & 16.1 & $2.0 / 2.4$ \\
\hline Sakisacaulon esterified in C-7 (7) & 53.9 & $13.6 / 18.3$ \\
\hline 3-Butyl-3,7-dihydroxy-5-methoxy-1(3H)-isobenzofurane (8) & $>100^{c}$ & \\
\hline Ursolic acidd & 14.4 & $4.5 / 6.6$ \\
\hline Sodium-orthovanadate $^{\mathrm{d}}$ & 5.6 & $3.0 / 6.6$ \\
\hline
\end{tabular}

starting at Leu110 and ending at Lys120, the WPD loop (residues Trp179 to Glu186) and the P-loop (residues His214 to Arg221) associated with the catalytic activity, and the extended topology secondary binding site already characterized for other PTP1B inhibitors (residues Arg45 to Pro51 and Phe256 to Gln262). We noticed that residues that were sometimes observed binding to inhibitors in other studies [22,23] (Gln21 to Phe30) were not retrieved in our study. In our simulation, 8 did not interact with the side of the pocket extended at the N-terminal extremity (Arg45Pro51), which corresponds to a part of the secondary binding site. By observing the features of the molecular models and by analyzing the in vitro activity of the eight compounds towards PTP1B, it appears that this last missing contact site might be associated with reduced bioactivity. This could be explained by the small size of 8 , which does not allow the compound to completely fill the PTP1B catalytic pocket from one side (the loop at Asn111 to Lys 120) to the other (the N-terminal part of the secondary binding site). Analysis of the contact frequency map also indicates that additional interactions of the compounds with the $\beta$-sheet located between the loop at Asn111 to Lys 120 and the residues 121 to 178 do not lead to a significant increase of PTP1B inhibition, con- firming the medium importance of the secondary binding site. As all the bioactive compounds were suggested to interact with the catalytic activity-related regions of the PTP1B protein, it appears that the sole hydrophobic property or topographical organization of the catalytic pocket is not sufficient to explain the differences between the bioactivities of $\mathbf{1}$ ( $\vee$ Fig. $\mathbf{4 a}$ ) to 7 . This also excludes the hypothetical modulation of their inhibitory action through long-range allosteric effects. As the two depsidones (1 and 2 ) showed at least two times lower $I C_{50}$ values than the other largesize compounds, except 6 , we suggest that the relative rigidity due to the closure of the central ring increases the inhibitory effects of these compounds. However, binding features seem to be conserved when comparing 1 and 2; their similar reactivity might be related to various hydrogen bond donors or acceptors (hydroxyl, carbonyl, and/or carboxyl groups in positions C-4, C-7, C-8, C$2^{\prime}$, and/or C-7'), which interact with PTP1B key amino acids in different ways ( $\bullet$ Fig. $\mathbf{4 b}$ shows it exemplary for $\mathbf{1}$ ). Moreover, neither a hydroxyl nor a methoxyl function at the C-4 position seems to have a significant effect, even if hydrophobicity is slightly increased in 1. The interaction pattern of 6 is also highly noticeable as it creates mainly hydrophobic contacts and only a single $\mathrm{H}$ - 


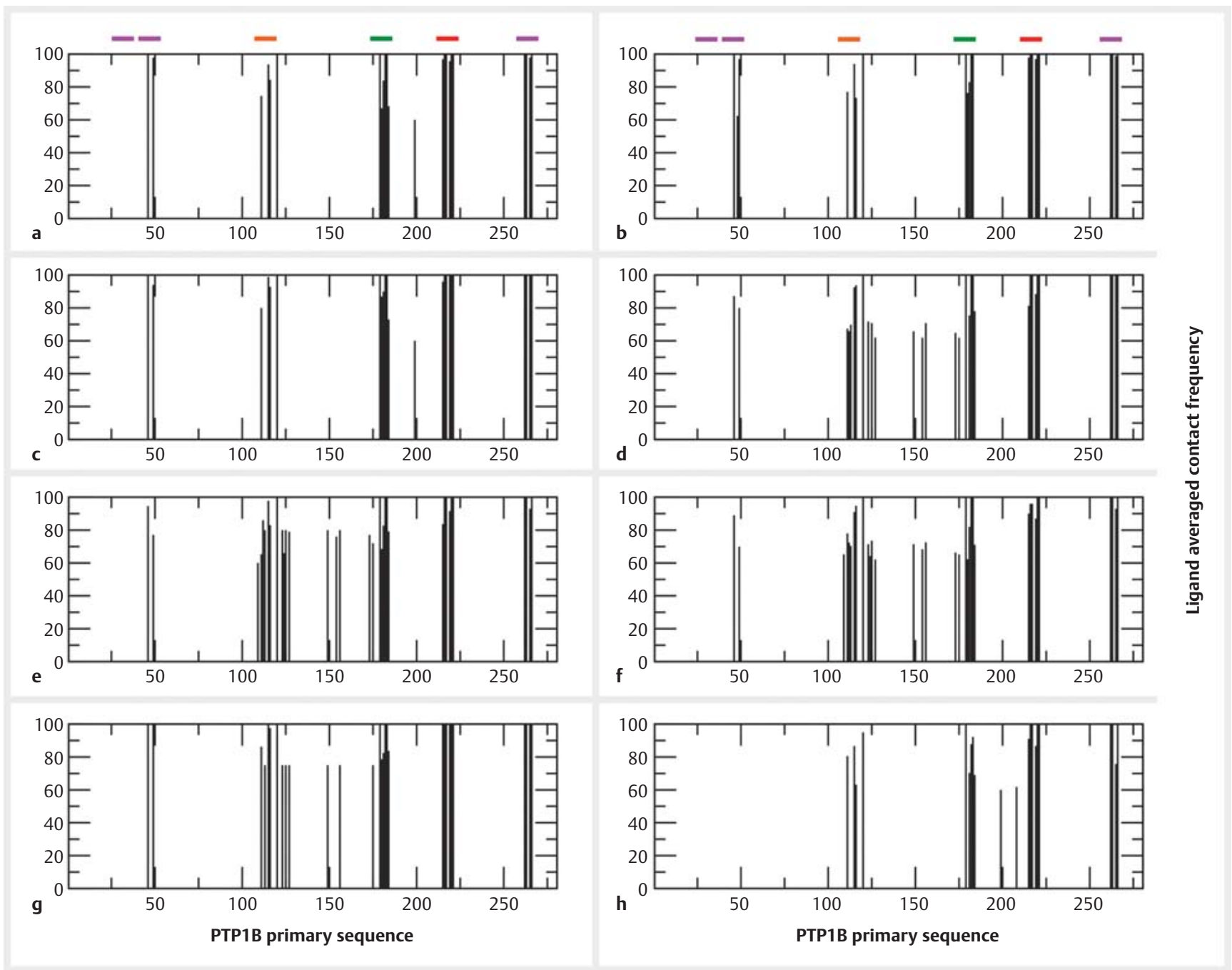

- Fig. 3 Averaged contact frequencies measured between compounds 1-8 (plots a to h, respectively) and the molecular models of the PTP1B protein obtained by homology modeling, normal mode analysis, and molecular dynamics simulations. The primary sequence of amino acids is shown on the X-axis, and regions already shown to be targeted by other PTP1B inhibitors are delimited by colored lines at the top of the graph: orange for the loop ranging from Asn111 to Lys120, green for the WPD loop ranging from Trp179 to Glu186, red for the P-loop ranging from His214 to Arg221, and violet for the extended topology secondary binding site involving residues Gln21 to Phe30, Arg45 to Pro51 and Phe256 to Gln266.

bond bridge between Arg221 and 0-7. However, we identified the amino acids Tyr46, Trp179, Ala217, and Ile219 as being involved in the stabilizing hydrophobic interactions with 1 and 2. The same residues were found to be involved in the dynamic binding of the aliphatic chains of several compounds to the enzyme. Finally, the bioactivity of 6 might be related to the electron distribution in the vicinity of C-8 due to the double bond.

Considering the weak activity of 3-5 and 7 and the inactivity of 8 , we noticed that, whereas the cycle opening observed in 7 seems to be related to a decreased efficiency in the inhibition of PTP1B compared to other compounds, our models highlight that an H-bond donor/acceptor at position C-8 (that binds to Thr263 and Asp265) could allow 7 to exhibit a better $I C_{50}$ than 5 . The same conclusion could be drawn after comparison of 4 to 5 ; the properties of the functions present at $\mathrm{C}-8(\mathrm{C}=\mathrm{C}, \mathrm{C}=\mathrm{O},-\mathrm{OH})$ seem to be a determinant for the inhibitory effects of our series. It was previously proposed that a carboxylic function at $\mathrm{C}-1^{\prime}$ increases the inhibitory effects of related compounds, but we can only confirm this observation in the case of the depsidones, whereas 3, possessing weaker activity, does not show a similar $\mathrm{H}$-bond network. Finally, the models of the less effective 5 and 7 both show a binding pattern involving a single $\mathrm{H}$-bond bridging Arg221 to O-7, a feature that should be avoided in case of functional optimization of the basic structure of lobaric acid derivatives. Indeed, other compounds that possess higher activities are involved in more complex H-bonding networks, assuring a stronger anchoring in the catalytic pocket (Fig. 24S, Supporting Information).

\section{Material and Methods}

\section{General procedures}

All solvents used for chromatography were purchased from Sigma-Aldrich. TLC was carried out on silica gel plates (silica gel 


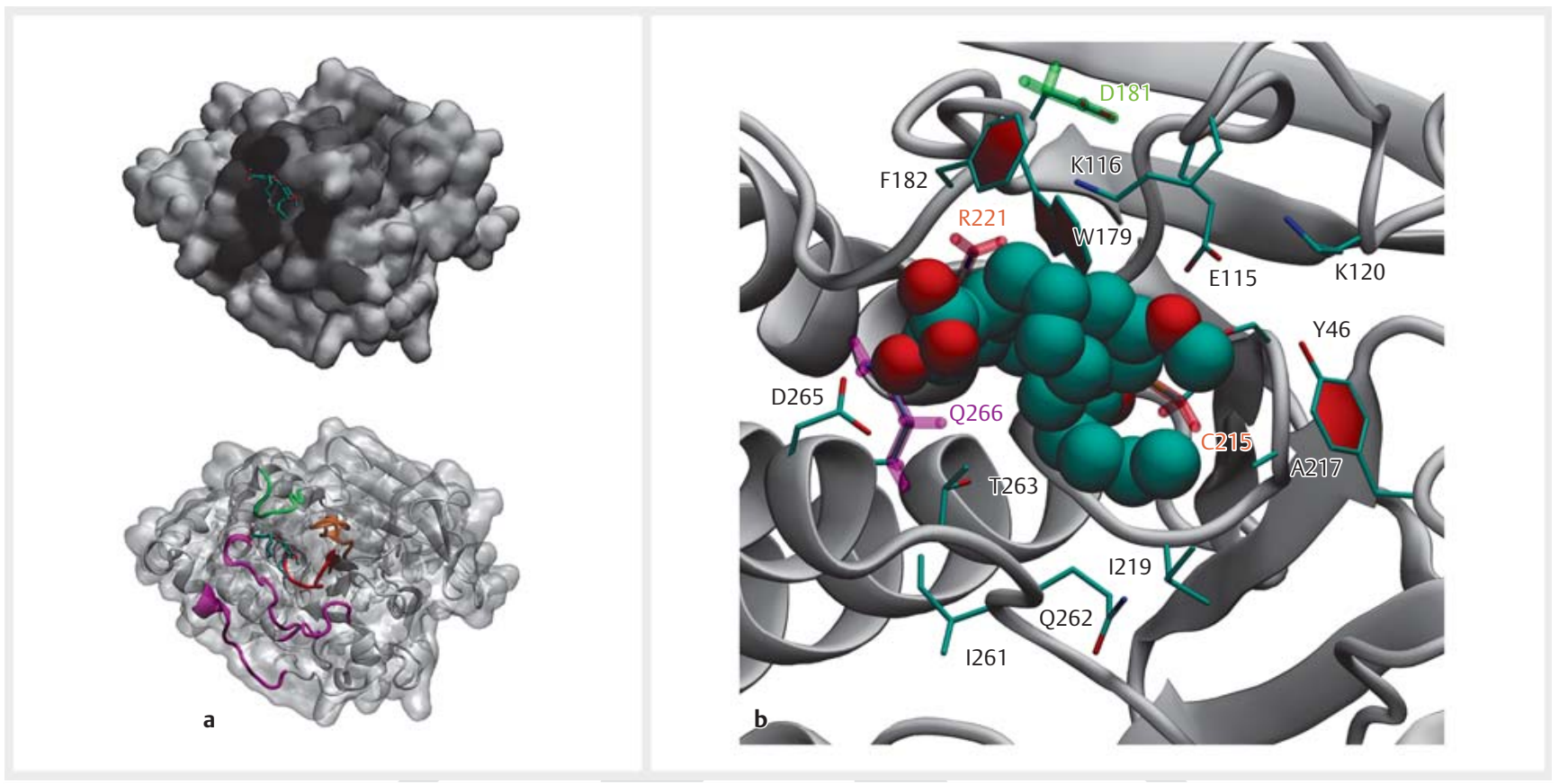

- Fig. 4 Best theoretical model for the complex formed upon the association of compound 1 with the PTP1B protein. a Position of compound 1 relative to the catalytic pocket of the PTP1B protein. The molecular hydrophobic potential has been computed with platinum software [24] and is allowing for the coloring of the molecular surface from white (hydrophilic, MHP $<0$ ) to black (hydrophobic, MHP $>0$ ). Topology elements are highlighted on the protein backbone following the same color code as used in $\mathbf{r}$ Fig. 3. b Contact sphere of compound $\mathbf{1}$ (van der Waals representation) after improvement of the best docking pose by a short molecular dynamic relaxation of the predicted theoretical complex. The side chains of amino acids within a distance of $4 \AA$ from compound 1 are shown as sticks. The catalytic residues Asp181, Cys215, Arg221, and Gln 262 are colored according to their belonging to topology regions (see $>$ Fig. 3 ).

60F254; Merck) with the following standard solvent systems for the identification of substances from lichens: B ( $n$-hexane/diethyl ether/formic acid 130:80:20), C (toluene/acetic acid 170:30), and $G$ (toluene/ethyl acetate/formic acid 139:83:8). The spots were first visualized under UV light and then after spraying with anisaldehyde- $\mathrm{H}_{2} \mathrm{SO}_{4}$ reagent. $\mathrm{CC}$ was carried out on silica gel (40-63 $\mu \mathrm{m}$, Kieselgel 60; Merck) or Sephadex LH-20. Mediumpressure liquid chromatography was conducted on a SPOT Liquid Chromatography Flash apparatus (Armen Instrument) using prepacked silica gel or RP-18 columns (Chromabond; Merck). The semipreparative chain included a Kontron series 325 pump with a DAD UV-visible detector (Kontron, 530A). ${ }^{1} \mathrm{H},{ }^{13} \mathrm{C}$, and 2D NMR spectra were recorded on a Bruker Avance III $400 \mathrm{MHz}$, a Bruker $300 \mathrm{MHz}$, or a Bruker $500 \mathrm{MHz}$ spectrometer with deuterated solvents. HR-MS measurements were carried out at the CRMPO to determine the exact masses, and on a Bruker Maxis $4 \mathrm{G}$, MicrO-Tof $\mathrm{Q} 2$, a Thermo-fisher Q-Exactive, or a Waters Q-Tof 2 mass spectrometer for chemical ionization. The MS system was coupled to an HPLC system including an autosampler SIL-20A HI, a 1100 Series binary pump (Agilent Technologies), and an SPD-M20A DAD UV-visible detector (Shimadzu) for the analytic chain using a Waters Spherisorb ODS2 C18 column ( $5 \mu \mathrm{m}, 150 \times 4.6 \mathrm{~mm})$ maintained at $40^{\circ} \mathrm{C}$ by a thermostat (CTO-20A). Ionization was performed by negative ion mode electrospray (ESI-). Full scan mass spectra were recorded in the negative ion mode in a mass range of 100 to $1200 \mathrm{Da}$, applying the following parameters: detector gain 1200 , ESI voltage $3.5 \mathrm{kV}$, capillary voltage $180 \mathrm{~V}$, source volt- age $20 \mathrm{~V}$, source voltage dynamic $20 \mathrm{~V}$, nebulizer gas pressure 60 psig, desolvation flow gas rate $4 \mathrm{~L} / \mathrm{min}$, capillary temperature $250^{\circ} \mathrm{C}$, and gas temperature $20^{\circ} \mathrm{C}$. Data processing and evaluation for the MS measurement were performed with the Data and Mass Express 2.2.29.2 software (Advion).

\section{Lichen material}

Specimens of S. evolutum were collected from siliceous rocks in Saint Just (Ille et Vilaine, France) by F. Le Dévéhat in November 2011 and identified by Claude Roux. A voucher specimen (JB/10/ 121) was deposited in the Herbarium of the Department of Pharmacognosy and Mycology of the University of Rennes 1 (France).

\section{Extraction and isolation}

The samples of S. evolutum (300 g) were first ground and the homogenized powder was successively extracted four times under agitation at room temperature for $24 \mathrm{~h}$ with $n$-hexane $(2 \mathrm{~L})$ and acetone $(1.5 \mathrm{~L})$, respectively. The acetone extract $(1.4 \mathrm{~g})$ was fractionated by flash chromatography on $\mathrm{C}_{18}$ gel (RS $40 \mathrm{C}_{18}$ ) using $\mathrm{H}_{2} \mathrm{O}$ with $0.15 \% \mathrm{TFA} / \mathrm{MeOH}(25: 85, v / v)$ as a mobile phase $(10 \mathrm{~mL} / \mathrm{min}, 75 \mathrm{~min})$, giving 75 fractions of $10 \mathrm{~mL}$ which were pooled according to their chromatographic profile to give seven subfractions (F1-F7). Fraction F2 (106 mg, $\mathrm{mL} 41-70)$ was chromatographed on a Sephadex LH-20 gel column $(1.5 \times 20 \mathrm{~cm})$ with diethyl ether $(100 \%, 200 \mathrm{~mL})$ to afford four fractions (F2a-F2d). Fraction F2b (35 mg, mL 11-50) was purified by preparative TLC developed with toluene/EtOAc/HCOOH (70:25:5, 
$\mathrm{v} / \mathrm{v} / \mathrm{v}$ ) to yield $10.3 \mathrm{mg}$ of 3 (Rf C: 0.17 , G: 0.44). Fraction F3 (103 mg, mL 71-100) was chromatographed on a silica gel column $(40-63 \mu \mathrm{m} ; 1.5 \times 25 \mathrm{~cm})$ with $\mathrm{CH}_{2} \mathrm{Cl}_{2} / \mathrm{Me}_{2} \mathrm{CO}(1: 0$, v/v, to $0: 1, v / v, 10 \mathrm{~mL}$ per solvent mixture) to obtain 4 (31.5 mg, Rf B: $0.48, \mathrm{G}: 0.47)$ at $20 \% \mathrm{Me}_{2} \mathrm{CO}$.

Silica gel CC $(2 \times 30 \mathrm{~cm})$ of fraction F5 $(408 \mathrm{mg}, \mathrm{mL} 151-400)$ by gradient elution using $n$-hexane/MeOH $(2: 8, v / v$, to $5: 5, v / v$, $10 \mathrm{~mL}$ per solvent mixture) through $\mathrm{CH}_{2} \mathrm{Cl}_{2}$ and EtOAc produced ten subfractions (F5a-F5j). Fraction $\mathrm{F} 5 \mathrm{c}$ ( $37 \mathrm{mg}, \mathrm{CH}_{2} \mathrm{Cl}_{2} / \mathrm{EtOAc}$ $80: 20)$ was then purified by semipreparative reversed-phase HPLC (Hypersil BDS C18 $5 \mu \mathrm{m}, 250 \times 10 \mathrm{~mm}$ ) using a gradient of ACN in $\mathrm{H}_{2} \mathrm{O}(52-65 \%, 2 \mathrm{~mL} / \mathrm{min}, 70 \mathrm{~min})$ to yield $5\left(4.5 \mathrm{mg}, \mathrm{t}_{\mathrm{R}}=\right.$ $37.17 \mathrm{~min}, \mathrm{Rf} \mathrm{C}: 0.20, \mathrm{G}: 0.54)$ and $6\left(17.1 \mathrm{mg}, \mathrm{t}_{\mathrm{R}}=46.31 \mathrm{~min}, \mathrm{Rf}\right.$ B: 0.53, C: $0.21, \mathrm{G}: 0.59)$. Compound 7 (6.0 mg, Rf B: 0.55, C: 0.24, Rf G: 0.59) was obtained from fraction F5f (27 mg, EtOAc) $\mathrm{MeOH} 90: 10)$ by semipreparative $\mathrm{HPLC}\left(\mathrm{C}_{18}\right)$ using $\mathrm{ACN} / \mathrm{H}_{2} \mathrm{O}$ $(50: 50, v / v)$ as a mobile phase $\left(2 \mathrm{~mL} / \mathrm{min}, 75 \mathrm{~min}, t_{R}=\right.$ $60.03 \mathrm{~min})$. Fraction F5g (110 mg, EtOAc/MeOH $80: 20)$ yielded a white, crystalline precipitate, which was separated from the supernatant by centrifugation, and then recrystallized in acetone to give 1 (24.3 mg, Rf B: 0.46, C: $0.41, \mathrm{G}: 0.61)$. The filtrate of fraction $\mathrm{F5g}$ was subjected to semipreparative $\mathrm{HPLC}\left(\mathrm{C}_{18}\right)$ with $\mathrm{MeOH} / \mathrm{H}_{2} \mathrm{O} / \mathrm{H}_{3} \mathrm{PO}_{4}(65: 35: 0.9, \mathrm{v} / \mathrm{v} / \mathrm{v})$ as a mobile phase $(2 \mathrm{~mL} /$ min, $\left.90 \mathrm{~min}, t_{R}=51.61 \mathrm{~min}\right)$ yielding $2(4.0 \mathrm{mg}$, Rf B: $0.51, \mathrm{C}$ : 0.43). Fraction F5h (112 mg, EtOAc/MeOH $60: 40$ ) was chromatographed on a silica gel column $(40-63 \mu \mathrm{m} ; 1.5 \times 25 \mathrm{~cm})$ eluted with $\mathrm{CH}_{2} \mathrm{Cl}_{2}$ /diethyl ether ( $1: 0, \mathrm{v} / \mathrm{v}$, to $5: 5, \mathrm{v} / \mathrm{v}, 10 \mathrm{~mL}$ per solvent mixture) through diethyl ether and $\mathrm{Me}_{2} \mathrm{CO}(1: 0,9: 1$, and $0: 1$, $\mathrm{v} / \mathrm{v}$ ) to afford $8\left(56.6 \mathrm{mg}\right.$, diethyl ether $/ \mathrm{Me}_{2} \mathrm{CO} 60: 40$, Rf B: 0.53 , C: $0.27, \mathrm{G}: 0.48)$.

3-Butyl-3,7-dihydroxy-5-methoxy-1(3H)-isobenzofurane (8): brown viscous liquid; Rf (silica gel 60 F254) 0.53 ( $n$-hexane/diethyl ether/formic acid 130:80:20), 0.27 (toluene/acetic acid 170:30), 0.48 (toluene/ethyl acetate/formic acid 139:83:8); UV (ACN:tetrahydrofuran, 1:1) $\lambda_{\max }(\log \varepsilon) 229$ (4.34), 259 (4.21), 295 (3.91) $\mathrm{nm} ;[\alpha]_{\mathrm{D}}^{25} 0.00$ (c 1.0, $\mathrm{CH}_{2} \mathrm{Cl}_{2}$ ); IR (KBr) $v_{\max } 3374,2957,1694$, $1614 \mathrm{~cm}^{-1} ;{ }^{1} \mathrm{H}$ and ${ }^{13} \mathrm{C}$ NMR: Table 35 , Supporting Information; ESI-MS (neg. ion mode) m/z $251.1[\mathrm{M}-\mathrm{H}]^{-}$; HR-ESI-MS m/z $275.0895[\mathrm{M}+\mathrm{Na}]^{+}$(calcd. for $\mathrm{C}_{13} \mathrm{H}_{16} \mathrm{O}_{5} \mathrm{Na}$ 275.0895).

\section{Determination of the protein tyrosine phosphatase 1B inhibitory activity in a cell-free assay}

Recombinant human PTP1B enzyme was purchased from R\&D Systems. Para-nitrophenylphosphate (pNPP), 3-(N-morpholino) propane sulfonic acid (MOPS), and dithiotheitiol (DTT) were obtained from Sigma-Aldrich. DMSO and $\mathrm{NaOH}$ were from Merck. Sodium-orthovanadate was obtained from Sigma-Aldrich with a purity of $99.98 \%$. Ursolic acid was purchased from VWR with a purity $\geq 97 \%$.

Enzyme activity of PTP1B was determined using $2 \mathrm{mM}$ pNPP in $50 \mathrm{mM}$ MOPS buffer, $\mathrm{pH} 6.5$, as a substrate in the presence of $1 \mathrm{mM}$ DTT. Extracts and compounds were first dissolved in $100 \%$ DMSO and then diluted with buffer to $1 \%$ DMSO in a $100 \mu \mathrm{L}$ final assay volume. Finally, PTP1B enzyme $(0.025 \mu \mathrm{g}$ in $5 \mu \mathrm{L}$ assay buffer) was added to the reaction mixture. PTP1B inhibitory activity was measured in quadruplicate using 96-well plates. To assure non-saturation, the reaction was subjected to kinetic absorbance readings at $405 \mathrm{~nm}$ for 30 min in a Hidex plate CHAMELEON photometer. Subsequently, the reaction was terminated by the addition of $10 \mathrm{M} \mathrm{NaOH}$ solution $(25 \mu \mathrm{L})$ and the absorbance was again read at $405 \mathrm{~nm}$. Potential absorbance of the tested extracts and compounds was also determined and subtracted from the readout.

Extracts and compounds were tested at 6-9 concentrations in three independent experiments, respectively, except for 7 at $300 \mu \mathrm{M}$, which was tested only once due to a lack of further material. Mean \pm SEM was plotted in the graphs. $I C_{50}$ values were calculated by fitting the data (log inhibitor vs. response, variable slope) using GraphPad Prism 5.01. The known PTP1B inhibitors ursolic acid and sodium-orthovanadate were used as positive controls.

\section{Molecular docking simulations}

To complete the PTP1B structure available from the Protein Data Bank (www.rcsb.org/), homology modeling of the full protein was performed for the completion of the missing residues by using I-Tasser (zhanglab.ccmb.med.umich.edu/I-TASSER/; accessed April 2018). After BLAST analysis, the best structural templates selected for model production were equally $1 \mathrm{lar}, 1 \mathrm{ygr}$, and 2jjd and the final homology model was of high reliability (C-score of 0.38 ). For the following docking simulations and improvement of theoretical complexes, only the PTP subdomain that bears the catalytic site of PTP1B (residues 1-280) was considered. Then, diversity was brought to the PTP1B core part by achieving either a normal mode analysis (NMA) or molecular dynamics (MD) trajectory computations on its homology model. Concerning NMA [25], EINémo (www.sciences.univ-nantes.fr/elnemo/; accessed in October 2018) was used to modulate global conformations available from the initial model, improving the variety of PTP1B models that has been used during docking simulations. According to ElNemo standard validation of essential modes, four more modes of PTP1B (modes 7-9 and 11) were added as receptors in docking computations. Finally, two additional models corresponding to the most representative structures extracted from two independent 4 nanoseconds MD trajectories were considered. Both of these MD simulations started from the theoretical complex composed of the homology PTP1B and the best docking pose of the compound. All PTP1B core models were geometrically improved through energy minimization performed with YASARA suite (version 18.12.27) [26] and standard parameters (energy minimization, Amber03 forcefield). Docking calculations were then performed by using the standard protocol proposed in the VINA implementation of YASARA (global docking, 1000 runs per target/ per compound). Parametrization of compounds $1-8$ was obtained by the well-proven and automated AutoSmiles procedure of YASARA. Frequencies for ligand-contacting residues were measured using a $4.0 \AA$ cutoff distance over a set of 7.000 theoretical complexes for each compound (four docking simulations with NMA PTP1B, two with MD PTP1B, and one with homology PTP1B). Models for the best theoretical complexes were obtained after clustering all concatenated results using the g_cluster command of Gromacs (version 5.0) [27] (Jarvis-Patrick method). The same clustering method was used to extract most representative theoretical complexes from MD trajectories and LigPlot+ (version 2.2) (www.ebi.ac.uk/thornton-srv/software/LigPlus/) allowed for plotting contact networks. 


\section{Supporting information}

Acetylation of 8 , NMR data $\left({ }^{1} \mathrm{H}\right.$ and $\left.{ }^{13} \mathrm{C}\right)$ of $1-8$, LC-MS analysis of 8 in crude $S$. evolutum extracts, suspected biogenetic relationships between $1,3-7$, and 8 , concentration-dependent inhibition of PTP1B by the $n$-hexane and the acetone extract of S. evolutum, concentration-dependent inhibition of PTP1B by 3-5 and 7, and contact networks between 1-8 and PTP1B are available as Supporting Information.

\section{Contributors' Statement}

Conception and design of the study: F. Lohézic-Le Dévéhat, B. Waltenberger, O. Delalande; data collection: T. H. Vu, S. Reider, O. Delalande, C. Lalli, S. Ferron, B. Waltenberger, F. LohézicLe Dévéhat; analysis and interpretation of the data: T.H. Vu, S. Reider, O. Delalande, C. Lalli, S. Ferron, J. Boustie, B. Waltenberger, F. Lohézic-Le Dévéhat; statistical analysis: S. Reider, B. Waltenberger; drafting of the manuscript: T.H. Vu, O. Delalande, C. Lalli, S. Ferron, J. Boustie, B. Waltenberger, F. LohézicLe Dévéhat; critical revision of the manuscript: B. Waltenberger, F. Lohézic-Le Dévéhat, J. Boustie.

Acknowledgements

We would like to express our thanks to the Centre Régional de Mesures Physiques de l'Ouest, Université de Rennes 1, France, for NMR and MS measurements. We are also grateful to the PRISM core facility (Rennes, France) for NMR spectrometer access and to Luca Pompermaier, Ph.D., for his support regarding the PTP1B assay. This research was supported by the Vietnam International Education Development.

\section{Conflict of Interest}

The authors declare that they have no conflict of interest.

\section{References}

[1] He RJ, Yu ZH, Zhang RY, Zhang ZY. Protein tyrosine phosphatases as potential therapeutic targets. Acta Pharmacol Sin 2014; 35: 1227-1246

[2] Barford D, Flint AJ, Tonks NK. Crystal structure of human protein tyrosine phosphatase 1B. Science 1994; 263: 1397-1404

[3] Thareja S, Aggarwal S, Bhardwaj TR, Kumar M. Protein tyrosine phosphatase 1B inhibitors: a molecular level legitimate approach for the management of diabetes mellitus. Med Res Rev 2012; 32: 459-517

[4] Yip SC, Saha S, Chernoff J. PTP1B: a double agent in metabolism and oncogenesis. Trends Biochem Sci 2010; 35: 442-449

[5] Catalano S, Barone I, Marsico S, Bruno R, Ando S. Phosphorylation processes controlling aromatase activity in breast cancer: an update. Mini Rev Med Chem 2016; 16: 691-698

[6] Thompson D, Morrice N, Grant L, Le Sommer S, Lees EK, Mody N, Wilson HM, Delibegovic M. Pharmacological inhibition of protein tyrosine phosphatase $1 \mathrm{~B}$ protects against atherosclerotic plaque formation in the LDLR(-/-) mouse model of atherosclerosis. Clin Sci 2017; 131: 24892501

[7] Gonzalez-Rodriguez A, Valdecantos MP, Rada P, Addante A, Barahona I, Rey E, Pardo V, Ruiz L, Laiglesia LM, Moreno-Aliaga MJ, Garcia-Monzon C, Sanchez A, Valverde AM. Dual role of protein tyrosine phosphatase 1B in the progression and reversion of non-alcoholic steatohepatitis. Mol Metab 2018; 7: 132-146
[8] Sun M, Izumi H, Shinoda Y, Fukunaga K. Neuroprotective effects of protein tyrosine phosphatase $1 \mathrm{~B}$ inhibitor on cerebral ischemia/reperfusion in mice. Brain Res 2018; 1694: 1-12

[9] Verma M, Gupta S], Chaudhary A, Garg VK. Protein tyrosine phosphatase $1 \mathrm{~B}$ inhibitors as antidiabetic agents - a brief review. Bioorg Chem 2017; 70: $267-283$

[10] Kerru N, Singh-Pillay A, Awolade P, Singh P. Current anti-diabetic agents and their molecular targets: a review. Eur J Med Chem 2018; 152: 436 488

[11] Rios JL, Francini F, Schinella GR. Natural products for the treatment of type 2 diabetes mellitus. Planta Med 2015; 81: 975-994

[12] Shrestha G, St. Clair LL. Lichens: a promising source of antibiotic and anticancer drugs. Phytochem Rev 2013; 12: 229-244

[13] Seo C, Sohn JH, Ahn JS, Yim JH, Lee HK, Oh H. Protein tyrosine phosphatase $1 \mathrm{~B}$ inhibitory effects of depsidone and pseudodepsidone metabolites from the Antarctic lichen Stereocaulon alpinum. Bioorg Med Chem Lett 2009; 19: 2801-2803

[14] Seo C, Yim H], Lee HK, Hyuncheol O. PTP1B inhibitory secondary metabolites from the antarctic lichen Lecidella carpathica. Mycology 2011; 2: $18-23$

[15] Vu TH. Etude des acides gras du genre Stereocaulon et étude phytochimique du lichen S. evolutum Graewe [Ph.D. Thesis]. Rennes: Université de Rennes; 2014

[16] Carpentier C, Queiroz EF, Marcourt L, Wolfender JL, Azelmat J, Grenier D, Boudreau S, Voyer N. Dibenzofurans and pseudodepsidones from the lichen Stereocaulon paschale collected in northern Quebec. I Nat Prod 2017; 80: 210-214

[17] Ingolfsdottir K, Gissurarson SR, Muller-Jakic B, Breu W, Wagner H. Inhibitory effects of the lichen metabolite lobaric acid on arachidonate metabolism in vitro. Phytomedicine 1996; 2: 243-246

[18] Millot M, Tomasi S, Articus K, Rouaud I, Bernard A, Boustie ]. Metabolites from the lichen Ochrolechia parella growing under two different heliotropic conditions. J Nat Prod 2007; 70: 316-318

[19] Ismed F, Lohezic-Le Devehat F, Delalande O, Sinbandhit S, Bakhtiar A, Boustie J. Lobarin from the Sumatran lichen, Stereocaulon halei. Fitoterapia 2012; 83: 1693-1698

[20] Morita H, Tsuchiya T, Kishibe K, Noya S, Shiro M, Hirasawa Y. Antimitotic activity of lobaric acid and a new benzofuran, sakisacaulon A from Stereocaulon sasakii. Bioorg Med Chem Lett 2009; 19: 3679-3681

[21] Gonzalez AG, Rodriguez EM, Bermejo J. Depsidone chemical transformations in an extract of the lichen Stereocaulon azoreum. An Quim 1995; 91 : 461-466

[22] Puius YA, Zhao Y, Sullivan M, Lawrence DS, Almo SC, Zhang ZY. Identification of a second aryl phosphate-binding site in protein-tyrosine phosphatase 1B: a paradigm for inhibitor design. Proc Natl Acad Sci U S A 1997; 94: 13420-13425

[23] Wang L], Jiang B, Wu N, Wang SY, Shi DY. Natural and semisynthetic protein tyrosine phosphatase 1B (PTP1B) inhibitors as anti-diabetic agents. RSC Adv 2015; 5: 48822-48834

[24] Efremov RG, Chugunov AO, Pyrkov TV, Priestle JP, Arseniev AS, Jacoby E. Molecular lipophilicity in protein modeling and drug design. Curr Med Chem 2007; 14: 393-415

[25] Suhre K, Sanejouand YH. ElNemo: a normal mode web server for protein movement analysis and the generation of templates for molecular replacement. Nucleic Acids Res 2004; 32: W610-W614

[26] Krieger E, Darden T, Nabuurs SB, Finkelstein A, Vriend G. Making optimal use of empirical energy functions: force-field parameterization in crystal space. Proteins 2004; 57: 678-683

[27] Hess B, Kutzner C, van der Spoel D, Lindahl E. GROMACS 4: algorithms for highly efficient, load-balanced, and scalable molecular simulation. J Chem Theory Comput 2008; 4: 435-447 